\title{
The Agapetic Attitude and the Future of Philosophy
}

\author{
Mary Carman Rose \\ Goucher College, Emeritus
}

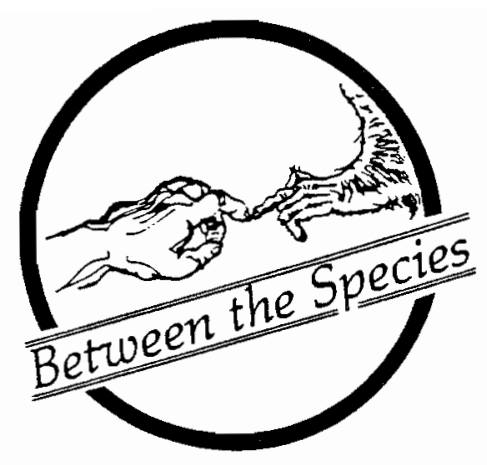

Editor's Note: The following paper was presented at the Central Division meetings of the Society for the Study of Ethics and Animals, held in New Orleans, Louisiana, April, 1990.

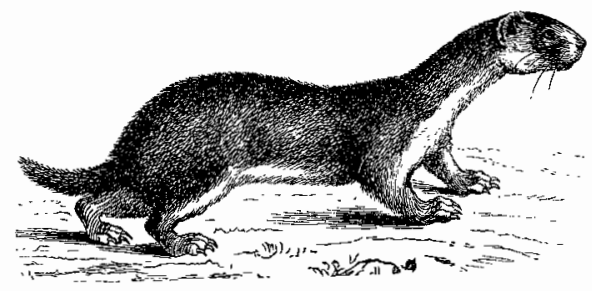

My thesis is that experience with, appreciation of, and concern for fostering the well-being of animals on the part of professional philosophers may have beneficial effects within philosophical inquiry and hence within our profession as teachers. This appreciation and concern for animals I will call the "agapetic attitude" (from "agape"). After providing background concerning human relations to other-thanhuman aspects of nature, I will argue that cultivation of the agapetic attitude toward animals may improve our capacities for observation and interpretation of what we encounter in the physical world; may lead to contemporary discernment of the value of the traditional understanding of the philosopher's attitude toward inquiry, and may bring about a burgeoning of creativity in respect to currently troubled realist/anti-realist discussions among philosophers. I will argue this on historical, experiential, and speculative grounds.

\section{Anthropocentrism in 20th Century Philosophy}

The mind and spirit of many contemporary Western philosophers have been shaped by diverse anthropocentric views which at least implicitly diminish,

\begin{abstract}
distort, or ignore the spontaneous appreciation of nature, which is a valued experience of many persons. It is not, however, only professional philosophers whose perspectives on nature have been affected by this anthropocentrism; anyone who has taught philosophy has encountered students who have somehow been already imbued with views akin to Sartre's concepts of en soi (in itself) and pour soi (for itself) as these apply to the physical world, while there has been little in 20th century Western philosophy to foster active appreciation of other-than-human aspects of nature. To be sure, there is now a burgeoning of world-philosophy, and the situation is different with some Eastern thought-e.g., the Zen response to birds, animals, and trees. But while an occasional 20th century Western philosopher is influenced by this or another Eastern attitude toward nature, not all Western philosophers are open to the appeal of Eastern thought, and a Western fostering of love of nature is needed to counteract the dominance of 20 th century anthropocentrism.
\end{abstract}

A person whose philosophical education began before 1950 may have encountered American Hegelianism, for which (according to most interpretations) no aspect of nature "in-itself" is a suitable object of any human interest. And by the early 20 th century there began the rapid succession to dominance of anthropocentric and implicitly anti-realist philosophical positions, notably critical realism, logical empiricism, instrumentalism, secular

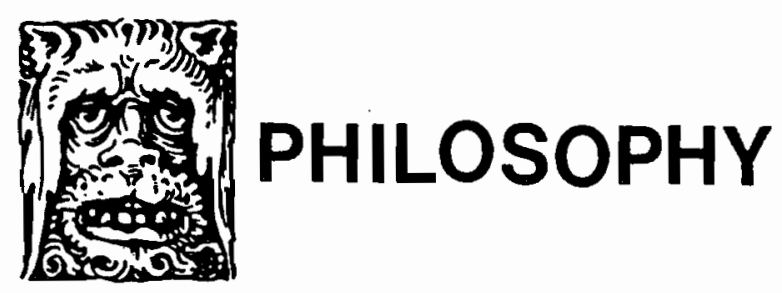


existentialism, several varieties of phenomenology, and-most recently-deconstructionism. The antirealism of these views is seen in the fact that each of them denies at least one of the four presuppositions of the agapetic attitude, which is necessarily based in the acceptance of a realist interpretation of nature. These presuppositions are that entities and processes of the physical world (e.g., and here specifically, the animals) have their "real nature" apart from human interest in them or opinions about them; that some of these can to some extent be known; that such knowledge has a profound existential effect within human life; and that commitment to learning about these objective things and states of affairs has great axiological import for the human spirit. Taken together these four presuppositions serve as a working definition of some forms of what is currently known as "realism." And I suggest that the denial of any one of these presuppositions constitutes a satisfactory working definition of "anti-realism."

\section{Experiences with Nature Ignored or Distorted by Anthropocentrism}

Clearly, defense of a speculative hypothesis requires articulation and defense of its presuppositions. Defense of all the presuppositions which shaped my hypothesis concerning the philosophical value of the agapetic attitude would, however, be too extensive for this essay. In this context only the following presupposition requires attention:ideally, any philosophical understanding of the physical world will, according to its own perspective, encompass human experiences within nature in a manner that neither rejects nor distorts them.

Anthropocentric interpretations of nature, on the other hand, fail to illumine adequately much human experience with nature which is of great significance to many humans and potentially to philosophical inquiry. There are features of our natural environment of which even the most consistent anti-realist must be aware, while in his concern with them he almost certainly introduces some realist considerations: e.g., the loci of possible earthquakes or the threat of a virus whose "real nature" is not yet known. And in the case of the anthropocentric thinker whose spirituality includes compassion, there may be the desire to ameliorate the suffering not only of individual humans but also of individual animals.

There are, however, aspects of our natural environment which are ineluctably present to virtually all humans but which only those with the requisite features of spirit and mind will discern, while among these only some will respond with great appreciation and a desire to foster them and our awareness of theme.g., the appeal of stars, mountains, birds and bird songs; of the plants we grow from seed and in which we watch daily the maturation of an organism in which fragrance, colors, and mathematical designs are inherent; and the perceptiveness, resourcefulness, needs and endearing characteristics of the animals to which we give an important role in our personal lives. And finally, only the person capable of the agapetic attitude will note and wish to alleviate the suffering of the animals.

On the other hand, anthropocentric interpretations of aspects of nature, such as those to which I have just called attention, do not illumine either the intrinsic or the instrumental values these have for some persons. First, a Hegelian interpretation of them circumvents the fact that it is precisely as other-than-human that these aspects of nature are precious to some of us. For example, I cherish as intrinsically valuable the delight, wonder, and mystery I know in the presence of the sparrows and squirrels outside my study window, while I am also grateful that these experiences leaven and revitalize my spirit.

Second, I cannot accept an anti-realist interpretation of nature as I know it in these appreciative responses. Undeniably, it is through my experiences that I know the aspects of nature which occasion these responses in me. Yet central to these experiences is the fact, which is also undeniable, that I am convinced that in them something of the surprise which always accompanies true wonder is given me, something I did not and could not put there, and something which invitationally calls me out of myself, giving me some very welcome moments of freedom from my self-concerns and from the self-consciousness to which a phenomenological stance can lead.

Third, I also value both instrumentally and intrinsically my desire to be actively concerned with fostering positive human responses to these aspects of nature. Hence, I cannot accept a deconstructionist suggestion that I experiment with supplanting this attitude with indifference to them. ${ }^{1}$ For I have a fund of experience which, I believe, supports my conclusion that I would do harm to myself as philosopher and as human being if I gave up (e.g., "deconstructed") my presupposition that because these experiences appeal to my capacities for wonder, spiritual and intellectual 
adventure, and compassion, they are permanently of great value to me spiritually, morally, and intellectually. I will develop this topic further below when considering the possible "deconstructive bracketing" of the agapetic attitude.

The foregoing will repay some analysis. There are two types of relation which I may have to the experiences I have named. First, there is my spontaneous unself-conscious response to particular entities or situations in nature, and, second, there is my reflection on a remembered moment of that selfforgetfulness before nature in wonder or concern, in response to what I find aesthetically pleasing or to the presence of mystery. In these latter indirect relations to nature, I recall my capacity for and experiences of self-forgetful appreciative response to other-thanhuman aspects of nature and the effects of these responses within my mind and spirit. Moreover, in this reflection on these experiences I find ingredients which are of the highest importance to me: my wonder that these objects and situations exist, my spontaneous presupposition I did not make them, my desire to assume a stewardship of them, and my vivid and cherished memory that in these experiences I am totally taken up with something not myself.

To be sure, some individuals may be unaware of, uninterested in, or even repelled by the aspects of nature which make these experiences possible for me. From my observations of others I have concluded that these persons seem to be "locked" within their own experiences. Whatever they encounter in nature they analyze as though its most significant aspect is that it is their experience. I am reminded of a colleague who during the 1940's, when American philosophy was dominated by logical empiricism, instrumentalism, critical realism, or a combination of these positions, referred to a St. Bernard dog as a "gestalt." To be sure an artist might on occasion speak of an animal in that manner. But I knew this person's philosophical preference and that his words were consciously intended to communicate his experience of the dog as a configuration of color, form, lines, and massive presence. According to my lights, however, this affectionate and intelligent animal possessed a very interesting subjectivity of its own which I believed I could discern only partially and indirectly.

There are a number of psychological, emotional, experiential, educational, and spiritual reasons why an individual might be capable only of an anti-realist interpretation of the physical world. This brings us to criticism of contemporary approaches to nature, an area of great significance for the spiritual and intellectual development of individuals per se, scientific inquiry, present-day philosophical creativity, ecological issues, and all compassionate, humane considerations. Three possible explanations of a preference for anti-realist interpretations of sensory experiences are (1) the narcissistic inability to take an interest in what is not one's experience; (2) a lack of experience, knowledge, or imagination concerning the multifaceted value of interpreting these experiences as encounters with otherthan-human entities which merit our wonder, appreciation, admiration, affection, and compassion; and (3) the effects of acceptance of one or a combination of the several forms of anti-realist anthropocentrism.

Before turning to consideration of the agapetic attitude in respect to the higher animals, we recall that some persons do not live in terms of an anthropocentric perspective on the physical world but, rather, "see" entities or situations in nature as having an objective existence apart from their experience of them. The capacity for this stance, however, is not always accompanied by the agapetic attitude. One may desire to achieve objective truth concerning nature yet be interested only in the import which that truth has for one's concerns. And having discerned this import, one may be only exploitative of nature. On the other hand, belief in some form of realism is necessary for enlightened, appreciative interest in what I will call "the whole animal", and I use that expression here to include the animal's "real nature," which it possesses by virtue of both its species and its idiosyncratic characteristics, and also its subjectivity as well as its behavior and appearance. Again, this may be a passive intereste.g., one's pleasure in contemplating what one believes one has discerned about lions, horses, or chipmunks. But it need not be passive; it may be a compassionate and active concern for the animals' well-being-i.e., it may be the agapetic attitude.

\section{The Higher Animals and the Agapetic Attitude}

Although none of the anthropocentric views is adequate to support agapetic reflection on the animals, some of these views have drawn attention to a dimension of philosophical inquiry which is useful in this context. From the several forms of phenomenology, existentialism, and instrumentalism we have learned 
that in some aspects of philosophical inquiry we not only may but must draw on our personal experiences. This I have done. In respect to what I believe I have discerned of the interior life of animals, however, I am able to be brief. For among those who have an appreciation of animals, these experiences are well known, although it is useful here to make explicit some concrete details on which I have based my conclusions.

I believe that in the animals I find their enjoyment of play; their delight in each other's companionship and in that of the humans they trust and love; and their desire to give and to receive affection in respect to other animals and also to humans. I also believe I have found in them concem for each other and some indication of their concern for me when I have been distressed. Again, I believe they have real emotional needs which arise from their fears, insecurities, anxieties, and physical pain, and, when I have been present on these occasions, I believe they have looked fixedly into my eyes not with peace and affection but with trust and expectation that I will come to their aid.

\section{Intellectual and Spiritual Roles of the Agapetic Attitude}

In at least three ways the agapetic attitude serves and is served by both the intellect and the spirit, whether or not the individual who sustains the attitude is a philosopher.

(1) Concerning the animals, the agapetic person will endeavor to think clearly, cautiously, and with integrity. For it is likely that spontaneously and unreflectively he desires to minimize human action in terms of a distorted conception of the nature of animals and a willingness to dominate them destructively. Hence, while implicitly he presupposes that he is able to achieve some understanding of the subjectivity of particular animals, ideally he is also willing to answer, rather than ignore, the charge that in this belief he is being anthropomorphic. For when this presupposition is undefended, the agapetic attitude toward animals is vulnerable. On the other hand, if his belief that he has knowledge of the subjectivity of some animals can be justified, then those who see this belief as anthropomorphic are rejecting opportunities to make discoveries about animals and the capacities of animals for subjective well-being or suffering. And, again, ideally, the agapetic person is willing to point this out, not wanting others to reject the opportunity for learning about the animals, for increasing the well-being of animals, and for ameliorating some of their suffering.

(2) This possibility bestows on the agapetic person the hope that in his encounter with animals he does not meet only the content and ethos of his own spirit projected on selected aspects of nature, although in the case of the person who is not a philosopher this hope is likely to remain unexamined. Besides his impulse to foster the well-being of animals, the agapetic person at least implicitly has an appreciation of the importance to his intellect and spirit of his accepting the adventure of discovery in respect to animal nature.

(3) Further, if there are animals to whom we are able to render good service, whether these animals enjoy being our companions or prefer to be alone in their uncultivated environment, then perhaps both nonphilosopher and philosopher need to reflect thoroughly and hopefully on the presupposition that we can genuinely come to know at least some characteristics of these animals. But how come to know them? Have we not learned from several varieties of anthropocentrism that in our reflection on any aspect of nature we are reflecting only on our human experiences of nature which are necessarily acculturated, and may be idiosyncratic? Here, as it did above, a contemporary deconstructionist approach comes to our aid. But now we will use this approach specifically in respect to our attitude toward the animals. Let us ask: What would be lost to us if we were to give up the agapetic attitude and supplant it with an indifference to the animals or a willingness to exploit and dominate them? But let us ask this question not only as intellectual exercise or as deliberate challenge to a fairly widespread interpretation of our relation to nature. Let us ask it, rather, as a part of our effort to justify the agapetic person's view that our observations are clues to the real nature of the animals.

We may ask this question in respect to both our own spirit and mind and our interpretation of those of others. And we ask it for the sake of gaining support for the hypothesis that the agapetic attitude has beneficial effects on the valuational nature and the intellect of the person who sustains it. Having tried this myself, I believe that there is no lack of evidence that the sustaining of the attitude has such effects. Thus, the individual's kindly, inviting attitude toward an animal 
can make a difference in the animal, freeing and enabling it to develop and/or to reveal some characteristics which otherwise might have remained dormant or hidden. Also, the individual becomes a more patient, discerning, and responsive observer of animals, and perhaps of other aspects of nature. And his kindness being reinforced by his awareness of the animals' positive response to him, he may develop a new or increased inclination to give kindness to humans.

\section{The Relevance of the Agapetic Attitude to Philosophical Inquiry}

What may legitimately be said concerning the effects of the agapetic attitude on philosophical reflection? In part my conviction of the philosophical importance of the agapetic attitude derives from my reflection on my experience-i.e., my common sense experience with the cultivation of that attitude; my experience which is derived from my giving the attitude roles in my own philosophical reflection; and my observing the effectiveness of the attitude in the lives and the philosophical inquiry of those philosophical colleagues in whose intellectual and spiritual stance I believe I have discerned it. Thus, I suggest that the agapetic attitude creates and develops in the person who sustains it the desire and the intention to encounter and to achieve some acquaintance with responsive forms of life that are not human. Furthermore, this person has truly self-forgetful moments when he aims to "bridge the species gap" in admiration, wonder, compassion, affection, delight in the mutuality of the companionship he has with some animals, his taking advantage of opportunities for doing acts of kindness for them, and his discovery of the animals as loci of the unknown and of mystery.

Further, the agapetic attitude needs to be continually shaped by a realism and hence has significance for realist/anti-realist issues. The realisms which support the agapetic attitude, however, will be diversified. The Hindu, Jew, Taoist, Christian, or naturalist may share the agapetic attitude, but their views of the content and structure of reality and of the investigative capabilities of the human mind will not be the same. This fact has a two-fold significance for contemporary philosophy. It brings both Eastern and Western thought into philosophical inquiry, thereby furthering the development of world philosophy, and knowledge of the de facto diversity of realist views may prevent a too narrow development of interest in realism.
As I have already suggested, the intellectuality and spirituality of the agapetic attitude make for more accurate and thorough discerning of what is before us in the animals than is possible without that attitude. The anti-realist believes that she cannot have knowledge or empathetic awareness of the animals per se. She discounts evidence that this belief is not true, although the realist is likely to believe that the anti-realist finds evidence in support of some form of realism in virtually all her encounters with nature. On the other hand, the realist whose spirit is not imbued with the agapetic attitude and who is indifferent to, or who wishes to exploit, the animals sees only what is of interest to her and interprets what she sees in terms of her own interests. This raises the question of whether the person who, possessing the agapetic attitude, loves and wishes for the well-being of what she observes, can be intellectually "objective." Of course, the immaturity or the pathology of love and concern lead to distortion in observation. The person who is capable of mature love and concern, however, wants to know what she loves according to its own nature and not according to her wishes.

There are also historical reasons for drawing the agapetic attitude into philosophical reflection. My spontaneous appreciation of this attitude was encouraged when, upon first reading the Dialogues of Plato, I found what seemed to me to be intimations of our present-day experience with the attitude and its roles in our lives. (Of course, one need not read Plato as I am reading him, but I think there is no compelling evidence against this reading.) I have in mind Plato's interest in the love of truth, of the areas in which we seek truth, and of the situations in which we use the truth we achieve. Thus, Plato draws attention to the lovers of philosophical truth: Diotima says of the philosophers' achievement of knowledge of the Ideas, "And this, Socrates, is the final cause of all our former toils...."2 Further, not all humans are philosophers, and Diotima sees the fulfillment of the "birth of beauty" as possible for persons who work faithfully with true opinion. ${ }^{3}$ In the "Symposium" there is an emphasis on eros, i.e., on our spiritual as well as our intellectual needs for truth, but there are other dialogues in which there is a promise of fulfillment of our needs not in being served by truth but in our serving truth. This is expressed, for example, in many poignant lines in the "Republic": e.g., "Observe, Glaucon, there will be no injustice in compelling our philosophers to have a care and a 
providence of others."4 On the other hand, although it could be cogently argued that agape is not unambiguously present in Plato's Dialogues, it is clear that agape is present in Bonaventura's admonition that we should not make the mistake of believing that "it suffices to investigate without wonder, examine without exaltation, ...know without love."

There are at least two aspects of the historical grounds for drawing the agapetic attitude into current philosophical reflection. First, I have suggested above that the view that investigative capacities increase when they are fired by the zeal of the agapetic attitude may become for us a philosophical hypothesis (i.e., not dogma, axiom, decision, or expression of preference) and as such may be assessed, developed, and defended by reference to our concrete experience with it. Second, if support for this hypothesis can be found, then this event may help introduce into philosophical inquiry an endeavor to find in the history of philosophy accomplishments which have value for us today, even though they were conclusions of minds educated within a culture incommensurate with ours. Willingness to assess the hypothesis conceming the permanent value of the agapetic attitude could give new import to historical studies and to societies dedicated to these studies.

Finally, those of us who teach and publish our philosophical reflections may have significant effects on the values and intellects of others. And one way we can plant the seeds of more adequate philosophical thought is by assessing for possible integration into our reflection aspects of our everyday lives that are of proven value to us yet are often ignored or rejected by philosophical inquiry. For some of us the importance of our agapetic attitude toward the higher animals is a prime example of highly valued aspects of our concerns upon which in our day philosophical significance is not often bestowed. And in this essay we have noted several areas of philosophy that might benefit substantially from attention to this attitude: the philosophical need for adequate observation of experience, issues of realism/ anti-realism, investigative roles of the thinker's attitude toward his inquiry, and the improvement of our attitudes to other-than-human aspects of nature and above all to the higher animals.

\section{Notes}

\footnotetext{
${ }^{1}$ See, for example, the "ethos" of Jacques Derrida's "I have forgotten my umbrella."

${ }^{2}$ Plato, "Symposium" in The Dialogues of Plato, trans. by B. Jowett (New York: Random House, 1937), Vol. I. p. 334.
}

${ }^{3}$ Ibid., page 331. (Steff. 206)

${ }^{4}$ Plato, "Republic", Book VII. p. 779. Op. Cit.

${ }^{5}$ Saint Bonaventura, The Mind's Road to God, trans. by George Boas (New York: Bobbs-Merrill, 1952), Prologue, p. 5 .

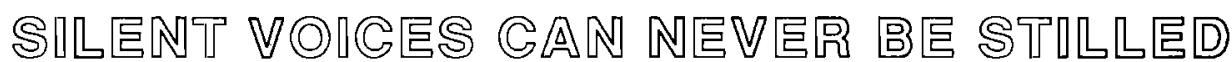

I stare at tree-covered mountain across the way,

Shuddering at repeated volleys.

In those woods walks beauty

That can't be destroyed or dragged out by hunters.

They've cheated themselves -

The corpses on car hoods are devoid of the Presence

Still in the woods,

Shadows walking quietly with those who come in peace. 